\title{
Leadership Styles and Management Techniques: An Analysis of Malaysian Women Entrepreneurs
}

\author{
Jayanty Kuppusamy, Jaya Ganesan and Sarah Aulia Rosada \\ Faculty of Business and Law, Multimedia University (Malacca Campus), Malacca, Malaysia
}

\begin{abstract}
Leaders of organizations need to lead and manage effectively to succeed. Thus, women entrepreneurs who are becoming more prominent in the business arena, have to be good leaders and managers. This study aims to identify the relationship of leadership styles which are charismatic and transformational and management techniques with organizational performance of women entrepreneurs in Malaysia. Questionnaires were sent to women entrepreneurs registered under NAWEM (National Association of Women Entrepreneurs of Malaysia). Correlation analysis and regression analysis were used to test the data. The result showed although both charismatic and transformation leadership and management techniques are utilized by the women entrepreneurs, however, the significant predictor of organizational performance is charismatic leadership.
\end{abstract}

Keyword: Charismatic, Transformational, Management Techniques

\section{Introduction}

Historically, entrepreneurship has been a male-dominated pursuit, but many of today's most memorable and inspirational entrepreneurs are women (Anonymous). Helms explains that women often start their own business for "three types of personal gains: personal freedom, security, and/or satisfaction" (Helms, 1997). In addition, Moore (2003) mentions women business owners cite a number of reasons for becoming entrepreneurs which are:

- Challenges/attractions of entrepreneurship;

- Self-determination/autonomy;

- Family concerns - balancing career and family;
- $\quad$ Lack of career advancement/discrimination; and

- Organisational dynamicspower/politics

Women entrepreneurs in Malaysia have increased due to the emphasis on industrialisation. According to Maimunah (1996a, 1996b), Malaysian women have been increasingly involved in various enterprises which were formerly maledominated. It was reported more than 82,000 or $16 \%$ were women owned companies with $89.5 \%$ of them involved in the services sector, $7.5 \%$ in manufacturing and $3.0 \%$ in the agricultural sector (The Department of Statistics of Malaysia, 2005). Furthermore, the support from the Malaysian government also provides the platform for women to become more involved in entrepreneurship. NAWEM

Copyright (C) 2010 Jayanty Kuppusamy, Jaya Ganesan and Sarah Aulia Rosada. This is an open access article distributed under the Creative Commons Attribution License unported 3.0, which permits unrestricted use, distribution, and reproduction in any medium, provided that original work is properly cited. Contact author : Jayanty Kuppusamy, e-mail: jayanty.kuppusamy@mmu.edu.my 
(National association of women entrepreneurs of Malaysia) was formed by the government with an objective to create an association that would assist women to develop and grow their businesses. Its mission is to provide the leadership and inspiration to act as a means of expression to the transformation of the role of women in business into a dynamic force (http://nawem.org.my/vision.htm). Other supportive ministries include Ministry of Entrepreneur and Cooperative Development (MECD) in May 1995 and the Ministry of Women, Family and Community Development (MWFCD) in 2001.Together; these ministries oversee the growth and development of existing and potential women entrepreneurs in the country. In addition, the women entrepreneurs are also given government grants and funds through the Small and Medium Industries Development Corporation (SMIDEC). Between August 1999 and August 2006, 523 women-owned companies were granted soft loans by SMIDEC worth a total of RM51.97 million. (Teoh, W.M.Y., \& Chong, S.C. 2007a).

The increasing importance of women entrepreneurs has raised an argument that their leadership style is different from their counterpart, male entrepreneurs. In comparing the management styles of women and men entrepreneurs, Bruni, Gherardi and Poggio (2004) explain that women display distinctive features and abilities, "transformational leadership". This type of leadership/management style encourages positive interactions and trustbased relationships with subordinates with whom they also share power and information. Gundry, Ben-Yoseph and Posig (2002) describe this as the "relational" practices engaged by women entrepreneurs. This would include collaborative, decentralized decisionmaking and an empowered team atmosphere. Their management style emphasizes open communication and "their business goals reflect a concern for the communities in which their businesses resided" (Gundry, Ben-Yoseph and Posig, 2002).

Derivation from transformational leadership, charismatic leadership is the process of influencing major changes in the attitudes and assumptions of organization members and building commitment for the organization missions or objectives (Yukl, 1989).

Leadership style and behaviors in women has been debated since a long time, because style is perceived as relatively stable pattern that is apparent by leaders. Based on a research done by previous researcher and expert, stated that the leadership style of women is mainly along the line that women is less hierarchical, more cooperative and collaborative, and more oriented to enhancing others' selfworth (Book, 2000; Helgelsen, 1990; Rosener, 1995).

Thus, this research aims to study the women entrepreneurships leadership styles from the two more recent leadership types, namely transformational and charismatic leadership style and also their management techniques and their relationship with organizational performance.

\section{Literature Review}

\section{Leadership}

Leadership is and has been described as the "process of social influence in which one person can enlist the aid and support of others in the accomplishment of a common task" Chemers, M. M. (2002). A definition more inclusive of followers comes from Alan Keith of Genentech who said "Leadership is ultimately about creating a way for people to contribute to making something extraordinary happen."(Kouzes, J., \& Posner, B. 2007). Successful leaders and entrepreneurs typically show a high internal locus of control (Lee, 2001).

\section{Charismatic Leadership Characteristics}

Charisma and charismatic leadership has been defined in various ways; a devotion to the specific and exceptional sanctity, heroism, or exemplary character of an individual person, or the normative patterns revealed or ordained by that person; endowment with the gift or divine grace; the process of influencing major changes in the attitudes and assumptions 
of organization members, and building commitment for the organization's objectives; leadership that has magnetic effect on people (Dubrin, 1995).Robert W. Rowden (2000) defines charismatic leadership as the behavioral tendencies and personal characteristics of leaders that create an exceptionally strong relationship between them and their followers. There are three personal characteristics of the charismatic leaders, which are extremely high confidence, dominance and strong convictions in his or her beliefs (Robbins \& Coulter, 2003; House, 1992).

Charismatic leaders demonstrate determination, optimism, and confidence in themselves and the collective ability to accomplish the mission and realize the vision (House and Shamir 1993). Charismatic leaders engender trust and taking personal risks in the name of their beliefs. They will show great confidence in their followers. They are very persuasive and make very effective use of body language as well as verbal language. Charismatic leaders will often focus strongly on making the group very clear and distinct, separating it from other groups. (Conger \& Kanungo 1998).

Charismatic leadership is mostly found in a new and struggling organization or in a failing organization, than in a stable and successful organization (Bass, 1985).

Conger \& Kanungo (1998) describe five behavioral attributes of Charismatic Leaders that indicate a more transformational viewpoint:

- Vision and articulation;

- Sensitivity to the environment;

- Sensitivity to member needs;

- Personal risk taking;

- Performing unconventional behavior.

Charismatic leadership, characterized by extraordinary leaders who usually emerge in a context of crisis or major change, this concept derives from individualized influence of transformational leadership (Yukl, 1994).

In short, charismatic leaders will be those managers or leaders who are able to spark the sense of belonging towards the leader and the organization, and inspire their followers or employees towards achieving the organizational goals and objectives (Schermerhorn, 2005; Row den, 2000).

\section{Transformational Leadership Characteristics}

Tucker and Russell (2004) stated that transformational leaders provide change and movement in their organizations. Such leaders seek to alter the existing structure and influence people to buy into a new vision and new possibilities. Excellent transformational leaders use authority and power to inspire and motivate people to trust and follow their example. Schuster (1994) stated that transformational leadership appeals to higher motivation and adds to the quality of life in the people and the organization. Transformational leadership provides energy-producing characteristics that generate new changes for the organization.

Transformational leaders elevate people from low levels of need, focused on survival (following Mallow's hierarchy), to higher levels (Kelly, 2003; Yukl, 1989). They may also motivate followers to transcend their own interests for some other collective purpose but typically help followers satisfy as many of their individual human needs as possible, appealing notably to higher order needs (e.g. to love, to learn, and to leave a legacy) (Feinberg, Strophe \& Burke, 2005 ). Dixon (1998) discovered inner characteristics of transformational leaders that produce effective behaviors. He indicated that self-confidence ('I can make a difference'), inner integrity, honesty, and personal values influence the leader's behavior. A key ingredient in effective performance is for the leader to connect his or her life experiences with transformational behaviors (Avoid, 1994). This inner connection and resulting behavior lead to external behaviors that transform the organization. For example, a sense of personal involvement produces a vision for the group (Schuster, 1994).

The leader's external and visible behavior has an impact on the organization (Avoid, 1994; Finkelstein \& Hambrecht, 1996). There is a 'cascading effect' from higherlevel leaders to lower-level leaders due to 
modeling effective behaviors, hiring others with similar behaviors, and behaviors being reinforced by the organization (Bass, Waldman, Avoid, \& Babb, 1987). The leader's behavior motivates and creates an impression that the leader has the competence and vision to achieve success (Keller, 1992). Changes in behavior are necessary to change culture (Trahant, Burke, \& Ounce, 1997).

\section{Management Techniques of Women Entrepreneurs}

According to Lowden (1987), there are four areas that an entrepreneur needs to develop in order to become a good manager-planning, organizing, leading and controlling. The entrepreneur through leading implements decisions, provides good organizational climate, ensures proper communication and develops the staff through training. In assessing the management practices of entrepreneurs, variations exist on how much emphasis an entrepreneur places on each of the skills. However, what skills are emphasized most or least by the entrepreneurs have yet to be identified with regards to women entrepreneurs

In order for women entrepreneurs to be successful, they have to look at the important aspects of managerial tasks, conflict handling and giving feedback to subordinates (Kouzes and Posner, 2002). Whetten et al. (2000) emphasized the importance of intrapersonal skills for effective management. This means in their perspective developing self-awareness on the basis of a thorough analysis of one's strengths and weaknesses. Understanding the interaction between people's preferences and their day-to-day workplace behavior is crucial for designing and implementing effective individual development efforts (Berr et al., 2000; Riding and Rayners, 1998).

Buttner (2001) reports that the management styles of women entrepreneurs was best described using relational dimensions such as mutual empowering, collaboration, sharing of information, empathy and nurturing. Importantly, these dimensions, which have also been associated with women in different professional occupations, were deemed to be associated with firm performance. According to Heffernan (2003), female negotiating styles have been shown to be different and it has been demonstrated that they are significantly more beneficial to long term business success. The most recent study that explored a genetic basis for special attributes of women in social ability and empathy imply a better performance of companies created and run by women because of their ability to communicate better with employees, suppliers and customers (Valencia, 2006).

\section{Characteristics of Successful Company Performance}

The studies done by Kaplan and Norton (1992, 1993, and 1996) and also Ventakataraman and Ramanujam (1986) found that organisational performance is a multidimensional construct tapping financial, operational, and customer related performance domains. Non-financial measures are found in the study by Fiorito and LaForge (1986), Chaganti, Chaganti and Mahajan, (1989). This method of measuring performance is adopted following suggestions of Gupta and Govindarajan (1984) and Dess and Robinson (1984) due to the problems and limitations associated with financial data in measuring performance of small firms. The owners' satisfaction with their organisation's performance is found to be used as one of the most important indicators of success (Luk, 1996). It is defined that the success of the small business as a level of performance equal to or exceeding the expectations of the firm's owner. One of the indicators used by Thompson and Strickland (1993) to measure performance are annual earnings, profitability, and return on investment. This study used the perception towards on achievement of profit, financial return as a measure of performance.

\section{Methodology}

The data was collected through the survey method. Questionnaire was used as the research instrument in collecting data. The 
questions were adopted from Dubrin A.J. (1995). The primary data was obtained from NAWEM (National Association of Women Entrepreneurs of Malaysia) members. A total of 100 questionnaires were sent to women entrepreneurs and 46 questionnaires were collected. Although a larger sample size would be preferable however, due to the nature of the difficulty to get the respondents the research was carried on with the available respondents. Besides, the Cronbach Alpha results show the reliability scale to be at an acceptable rate.

Table 1: Reliability Results

\begin{tabular}{|l|l|}
\hline & Alpha Value \\
\hline Charismatic Characteristics & 0.824 \\
\hline Transformational Characteristics & 0.662 \\
\hline Management Techniques & 0.838 \\
\hline Organizational Performances & 0.743 \\
\hline
\end{tabular}

\section{Results and Discussion}

The respondents mainly were aged from 41 to $45(43.5 \%)$, followed by those below 30 (28\%), 31-40 (15\%) and 46 and above $(13 \%)$. There is a well spread in terms of marital status with $50 \%$ being married while $45 \%$ are single and around $4 \%$ are divorcee. Most of the respondents are graduates $(80 \%)$. Business orientation of the respondents is mostly related to soft business such as service and retailing (63\%). The women entrepreneurs business ownership consist of full ownership $(17.4 \%)$, share with family $(32.6 \%)$, share with partner $(30.4 \%)$ and share with husband $(19.6 \%)$. Their business size is small where it is mostly less than 50 employees $(87 \%)$. The age of the business is mostly less than 10 years old which is around $78.3 \%$. Slightly more than half of the respondents have working experience $(52.2 \%)$. However, majority of them do not have business experience previously (78.3\%).

Factors analysis was conducted and charismatic characteristics were divided into 3 groups (Ch1, Ch2, and $\mathrm{Ch} 3$ ), transformational characteristics into 2 groups (Tr1 and $\operatorname{Tr} 2$ ) and managerial techniques were divided into 6 groups (Mt1, Mt2, Mt3, Mt4, Mt5 and Mt6). Organizational performance is represented by 1 group (f1). Correlation analysis was conducted to identify the relationship of charismatic, transformational and management techniques with organizational performance. The following tables present the correlation analysis result accordingly

Table 2: Results of Correlation Analysis between Charismatic Characteristics, Transformational Characteristics and Organizational Performance

* Significant at 0.005 level

\begin{tabular}{|l|l|l|}
\multicolumn{3}{|c}{ f1 } \\
\hline & \multicolumn{1}{c|}{ r } & Sig \\
\hline Ch1 & $0.363^{*}$ & 0.013 \\
\hline Ch2 & $0.309^{*}$ & 0.037 \\
\hline Ch3 & $0.592^{* *}$ & 0.000 \\
\hline Tr1 & $0.395^{* *}$ & 0.007 \\
\hline Mt2 & $0.340^{*}$ & 0.021 \\
\hline Mt3 & $0.391^{*}$ & 0.007 \\
\hline Mt5 & $0.370^{*}$ & 0.011 \\
\hline Mt6 & $0.316^{*}$ & 0.032 \\
\hline
\end{tabular}

** Significant at 0.001 level 
There is a significant relationship between charismatic characteristics and organizational performance. All the characteristics tested were found to have significant relationship with performance. They are being visionary, being expressive to employees, and willingness to take risk, good communication skills, inspiring trust, believe in employees' capability, being energetic and ready for action, having strategies to solve problems, can handle crisis and is able to self promote personality. This finding is line with previous studies; having leadership that has magnetic effect on people (Dubrin, 1995) trust, risk taking, visionary, persuasive (Conger and Kanungo, 1998), and projecting self confidence (Bass, 1985). Transformational characteristics are also found to have significant relationship with organizational performance. The characteristics are assisting raising employee's awareness, helping employee looking beyond self interest and commitment towards achievement. As Bass, Waldman, Avoid and Babb (1987) states there is a 'cascading effect' from higher-level leaders to lower-level leaders due to modeling effective behaviors and behaviors being reinforced by the organization. The leader's behavior motivates and creates an impression that the leader has the competence and vision to achieve success (Keller, 1992). The results above indicated managerial techniques are also significantly related to organizational performance Among the techniques are put emphasis of respect, giving and receiving feedback, involve in employees' progress, encourage employee participation in decision making, set high standard for employees, implement suggestion from employees, managing conflict benefiting both sides and maintain a friendly working environment. The results are line with the study by Kouzes and Posner (2002) who mentions on aspects of managerial tasks, conflict handling and giving feedback to subordinates, Whetten et al. (2000) who found importance of intrapersonal skills for effective management and understanding the interaction between people's preferences and their day-to-day workplace behavior (Berry et al., 2000; Riding and Rayners, 1998).

Next, the results of the relationship of demographic characteristics and organizational performance were presented.

Table 3: Results of Correlation Analysis between Demographic Characteristics and Organizational Performance

\begin{tabular}{|c|c|l|}
\multicolumn{1}{l|}{$\mathrm{f} 1$} \\
\hline Education & $-0.292^{*}$ & Sig \\
\hline Size & $0.356^{* *}$ & 0.049 \\
\hline
\end{tabular}

* Significant at 0.005 level

** Significant at 0.001 level

Only education and size of business have found to have a relationship with organizational performance. The result indicated the bigger the size of business the better the performance of the business is. This could be because of the availability of more resources in bigger business. However, the negative correlation between education and organizational performance meant the non graduate business women entrepreneur are performing better.
Independent t-test was carried out to identify the difference in performance for those with employment experience and business experience. No significant difference was found between those with employment experience and those without in terms of performance. Similar results were obtained for business experience. 
Next, regression analysis was used to identify the predictor of organizational performance. The result is presented below.

Table 4: Results of Regression Analysis between Charismatic Characteristics, Transformational Characteristics, Demographic Characteristics and Organizational Performance

\begin{tabular}{|l|l|l|}
\hline & R square & Sig \\
\hline Ch3 & 0.384 & 0.000 \\
\hline
\end{tabular}

Dependent variable: $\mathrm{f1}$

Significant predictors are Charismatic characteristics (Ch3) which is having strategies to solve problems, able to handle crisis and is able to self promote personality. This contributes 38\% towards organizational performance.

\section{Conclusion}

Charismatic leadership style is found to be more utilized by women entrepreneurs when associated with organizational performance. This could be because women are more in service oriented in business which requires charismatic style and also the nature of the gender which has advantage in persuasive skills (Conger \& Kanungo 1998). In addition, Conger \& Kanungo (1998) describe being sensitive to the environment and member needs are attributes of charismatic style. Transformational leadership is more associated with change and thus, would probably be used if the women entrepreneurs decide to make major changes in their organization. Nevertheless, leadership styles do have an impact on organizational performance. Therefore, a suitable style should be used to ensure success in organizational performance. As part of the government initiative to upgrade women entrepreneurs, leadership and management techniques should be emphasized in the training module.

This study had been able to show the leadership styles and management techniques of the women entrepreneurs.
Nevertheless, a limitation of this study is the sample size. A larger sample can be used in future studies, in addition to combining manufacturing and service industry. Another area of future study is to identify the difference between male and female entrepreneurs focusing on these two leadership styles.

\section{Reference}

Anonymous, (2009), "Famous Women Entrepreneurs", .[Online], [Retrieved August 10, 2009],

http://entrepreneurs.about.com/od/

famouswomenentrepreneurs/

Famous_Women_Entrepreneurs.htm.

Avoid, B. (1994), 'The "natural": Some antecedents to transformational leadership,' International Journal of Public Administration, 17, 1559-1581.

Bass, B. (1985), "Leadership: Good, better, best," Organizational Dynamics, 13, 26-40.

Bass, B., Waldman, D., Avoid, B., and Babb, M. (1987), "Transformational leadership and the falling dominoes effect," Group \& Organization Studies, 12(1), 73-87.

Berr, SA., Church, AH., and Waclawski, J.(2000), "The right personality is everything: linking personality preferences to managerial behaviors," Human Resource Development Quarterly, 11(2), 133-57.

Book, EW. (2000), Why the best man for the job is a woman, HarperCollins, New York.

Bruni. A, Gherardi. S, and Poggio. B.(2004), "Entrepreneur-Mentality, Gender and the Study of Women Entrepreneurs," Journal of Organizational Change Management, 17(3), 256-268.

Buttner, EH.(2001), "Examining female entrepreneurs' management style: An application of a relational frame," Journal of Business Ethics, 29(3), 253-269.

Chaganti, R., Chaganti, R., and Mahajan V. (1989), "Profitable Small Business 
Strategies Under Different Types of Competition," Entrepreneurship Theory and Practice,13(3), 21-35.

Chemers, MM. (2002), Cognitive, social, and emotional intelligence of transformational leadership: Efficacy and Effectiveness. Multiple Intelligences and Leadership, Reggie, RE., Murphy, SE., and Pirozzolo. FJ., (ed).

Conger, J., \& Kanungo, RN.(1998), Charismatic leadership in organizations, Sage Publications, Thousand Oaks, CA.

Department of Statistics Malaysia. (2005).

Dixon, D. (1988), "The balanced CEO: A transformational leader and a capable manager," Healthcare Forum Journal, 41, 26-29.

Dubrin, Andrew, J. (1995), Leadership: research findings, practice, and skills, Boston: Houghton Mifflin Company.

Feinberg, BJ., Ostroff, and Burke, WW. (2005), "The role of within-group agreement in understanding transformational leadership," Journal of Occupational and Organizational Psychology, 78, 471-488.

Finkelstein, S., and Hambrick, D. (1996), Strategic leadership: Top executives and their effects on organizations, St. Paul, MN: West Publishing Company.

Fiorito, SS., and Laforge R.W. (1986), "A Marketing Strategy Analysis of Small Retailers," American Journal of Small Business, 10(4), 7-17.

Gupta, AK., and Govindaraja V. (1984), "Business Unit Strategy, Managerial Characteristics, and Business Unit Effectiveness at Strategy Implementation." Academy of Management Journal, 27, 2541.

Gundry. LK., Ben-Yoseph. M., and Posig. M. (2002), "Contemporary Perspectives on Women's Entrepreneurship: A Review and Strategic recommendations," Journal of Enterprising Culture , 10(1), 67-86.
Heffernan, M. (2003), "Changing The Game," Prowess Conference, 2003, 1-15.

Helgesen, S. (1990), The female advantage: Women's ways of leadership, New York: Doubleday/Currency.

Helms. M.(1997), "Women and Entrepreneurship: The Appealing Alternative," Business Perspectives, 10(1), 16-19, Gale Group - Information Integrity.

Hersey, P., and Blanchard, KH. (1996), The Management of Organizational Behavior, Prentice-Hall, Englewood Cliffs, NJ.

Hinkin, TR. and Tracey, JB. (1999), "The relevance of charisma for transformational leadership in stable organizations," Journal of Organizational Change Management, 12, 105-119.

House, RJ.(1992), "Charismatic Leadership in Service-producing Organizations," International Journal of Service Industry Management, 3(1), 5-16.

House, RJ., and Shamir, B.(1993), Toward the integration of transformational, charismatic, and visionary theories. Leadership theory and research: Perspectives and directions, Chemers , MM., and Ayman ,R., (ed) 81-107, San Diego, CA: Academic Press.

Kaplan, RS., and Norton, D.P.(1992) "The balanced scorecard - measures that drive performance," Harvard Business Review, January-February, 71-9.

Kaplan, RS., and Norton, DP.(1993), "Putting the balanced scorecard to work," Harvard Business Review, SeptemberOctober, 134-47.

Kaplan, RS., and Norton, DP,(1996), “Using the balanced scorecard as a strategic management system," Harvard Business Review, January-February, 75-85.

Keller, R. (1992), "Transformational leadership and the performance of research and development project groups," Journal of Management, 18, 489-501. 
Kelly, ML. (2009), Academic advisers as transformational leaders. The Mentor.[Online], [Retrieved August 3, 2009],

http://www.psu.edu/dus/mentor/030101 mk.htm.

Kouzes, J., and Posner, B. (2007), The Leadership Challenge, CA: Jossey Bass.

Kouzes, JM., \& Posner, BZ.(1987), The leadership challenge: How to get extraordinary things done in organizations, San Francisco: Jossey-Bass Publishers.

Kouzes, JM. and Barry ZP.(2002), The Leadership Challenge, San Francisco: Jossey-Bass,.

Lee, Don \& Tsang, Eric. (2001), "The effects of entrepreneurial personality background and network activities on Venture Growth," Journal of Managerial Studies, 38(4), 583602.

Lowden, J S.(1986), "Management Skills for the Entrepreneurs", Entrepreneur, 35-39.

Luk, TK. (1996), "Success in Hong Kong: Factors self-reported by successful small business owners," Journal of Small Business Management, July, 34, 68-74.

Maimunah, I.(1996a), "Gender needs analysis of women entrepreneurs," Journal of Social Science and Humanities, 4(1), 1-9.

Maimunah, I.(1996b),“Usahawan wanita: Satu analisis keperluan dari perspektif gender,' Dalam Mazanah Muhamad dan Ezhar Tamam (eds.). Rakan Kongsi, Komunikasi dan Media dalam Pembangunan. Serdang: Penerbit Universiti Pertanian Malaysia, 55-76.

Moore, DP. (2003), "Women: Are you ready to be entrepreneurs?" Business and Economic Review, 49(2), 15-21.

Musser, SJ. (1987), The determination of positive and negative charismatic leadership, Grantham: PA: Messiah College.

$\begin{array}{lcr}\text { National } & \text { Women } & \text { Entrepreneurs of } \\ \text { Malaysia } & (2009),[\text { Online],[Retrieved } \\ \text { August } & 10, & 2009], \\ \text { http://nawem.org.my/vision.htm. }\end{array}$

Riding, R., Rayner, S. (1998), Cognitive Styles and Learning Strategies: Understanding Style Differences in Learning and Behaviour, Fulton, London.

Robbins, S.P. \& Coulter, M. (2003), Management, 7th edition. Prentice-Hall.

Rosener, JB. (1995), America's competitive secret: Utilizing women as a management strategy, New York: Oxford University Press.

Rowden, RW. (2000), "The Relationship between Charismatic Leadership Behaviors and Organizational Commitment," Leadership \& Organization Development Journal, 2000, 21:1, pp. 30-35.

Schermerhorn, JR. (2005), Management, 8th edition. John-Wiley \& Sons, Inc.,

Schuster, J. (1994), “Transforming your leadership style," Association Management, 46 (1), 39-43.

Teoh, WMY., \& Chong, SC. (2007a), "Women Entrepreneurship in Malaysia: A Framework of Factors Influencing Performance," Proceedings of the Seventh Asian Academy of Management Conference 2007: Reimagining Management in an Era of Multiple Crisis: Success and Sustainability of Business in Dynamic Asia, May 21 - 25, 2007a.

Thompson, AA., \& Strickland III AJ. (1993), Strategic Management, Concepts and Cases, Fifth Edition .

Trahant, B., Burke, W., \& Koonce, R. (1997), "12 principles of organizational transformation," Management Review, 86, 17-21.

Tucker, Bruce A. and Russell Robert F.(2004), "The Influence of the Transformational Leader," Journal of Leadership \& Organizational Studies, 10, 103-111.

Valencia, MM. (2006), Female Entrepreneurs: Past, Present and Future, [Online], [Retrieved September 8, 2009, http://www.cladea.org/leadership/textos/ FEMALE\%20ENTREPRENEURS.doc 
Venkatraman, N., \& Ramanujam, V. (1986), "Measurement of business economic performance, a comparison of approaches," Academy of Management Review, 11, 80114.

Whetten, D., Cameron, K., Woods, M. (2000), Developing Management Skills for Europe, 2nd ed., Pearson Education, Harlow.

Yukl, G. (1994), Leadership in Organizations, Prentice-Hall Englewood Cliffs, NJ.

Yukl, G.A. (1989), Leadership in Organizations, Prentice Hall Englewood Cliffs, NJ. 